\title{
New amine adducts with carbon dioxide as blowing agents in the production of integral polyurethane foams*)
}

\author{
Leonard Szczepkowski ${ }^{1)}$, Joanna Ryszkowska ${ }^{2)}$, Monika Auguścik-Królikowska ${ }^{2)}$, \\ Milena Leszczyńska ${ }^{2), * *)}$, Adam Przekurat ${ }^{1)}$, Sylwia Przekurat ${ }^{1)}$
}

DOI: dx.doi.org/10.14314/polimery.2020.10.3

\begin{abstract}
Blowing agents play an important role in the production of cellular polyurethanes. The traditional chemical blowing agent $\mathrm{H}_{2} \mathrm{O} / \mathrm{CO}_{2}$ did not meet all application requirements. This led to the introduction of physical foaming agents in the 1950-1960s, which were subject to four further modifications due to climatic hazards. The recently introduced new generation of hydrofluoroolefins (HFOs) hydrocarbons is currently in the application assessment and meets the utility and climate requirements for now. Without waiting for a long-term final assessment of this blowing agent group, an attempt was made to introduce carbon dioxide in the form of adducts with aliphatic amines into the foaming process. As example compounds, $\mathrm{CO}_{2}$ adducts with aliphatic hydrocarbons containing also primary, secondary and tertiary nitrogen atoms in the same molecule were used. The synthesis of adducts was carried out by the absorption of carbon dioxide gas in a solution of amines in monoethylene glycol (MEG) and triethanolamine (TELA). The resulting solutions containing $12-16 \mathrm{wt} \% \mathrm{CO}_{2}$ were next used in the application-oriented study. Amines regulating the foaming and gelation processes were used for the production of adducts, which allowed the elimination of organometallic gelling additives. Selected adducts were checked during the production of furniture chair seats on an industrial scale, obtaining integral foams in the range of density $190-294 \mathrm{~kg} / \mathrm{m}^{3}$ and hardness $22-38^{\circ} \mathrm{ShA}$. In the production process of these foams carried out at PLASTPUR a double-stream foaming machine from Hennecke was used.
\end{abstract}

Keywords: blowing agents, carbon dioxide adducts, integral foams, polyurethane foams.

\section{Nowe addukty amin $\mathrm{z}$ ditlenkiem węgla jako porofory $\mathrm{w}$ produkcji integralnych pianek poliuretanowych}

Streszczenie: Środki porotwórcze odgrywają istotną rolę w produkcji poliuretanów (PUR) komórkowych. Tradycyjny chemiczny środek porotwórczy, jakim jest $\mathrm{H}_{2} \mathrm{O} / \mathrm{CO}_{2}$, nie spełnia wszystkich wymagań aplikacyjnych, co doprowadziło w latach 1950-1960 do wprowadzania na rynek fizycznych środków spieniających - hydrofluoroolefin (HFO). Jednak ze względu na zagrożenia klimatyczne wynikające $\mathrm{z}$ ich stosowania poddawano je kolejnym czterem modyfikacjom. Ostatnio opracowana, nowa IV generacja węglowodorów typu HFO spełnia wymagania użytkowe i klimatyczne i obecnie jest na etapie oceny aplikacyjnej. Nie czekając na ocenę końcową tej grupy poroforów, podjęto próbę wykorzystania do procesu spieniania PUR ditlenku węgla w postaci adduktów z aminami alifatycznymi. Jako związki przykładowe użyto addukty $\mathrm{CO}_{2} \mathrm{z}$ węglowodorami alifatycznymi zawierającymi w tej samej cząsteczce także atomy azotu I-rzędowe, II-rzędowe oraz III-rzędowe. Syntezę adduktów prowadzono metodą absorpcji gazowego ditlenku węgla w roztworze amin w glikolu monoetylenowym (MEG) i trójetanoloaminy (TELA). Otrzymane roztwory zawierające $12-16 \%$ mas. $\mathrm{CO}_{2}$ stosowano w dalszych badaniach aplikacyjnych. Do wytwarzania adduktów użyto aminy regulujące procesy spieniania i żelowania, co pozwoliło na eliminację metaloorganicznych dodatków żelowania. Wytypowane addukty zastosowano w produkcji w skali przemysłowej siedzisk do krzeseł meblarskich, wytworzonych z pianek integralnych o gęstości z zakresu $190-294 \mathrm{~kg} / \mathrm{m}^{3}$ oraz twardości $22-38{ }^{\circ} \mathrm{ShA}$. W procesie otrzymywania

\footnotetext{
1) FAMPUR Adam Przekurat Company, Gersona 40, 85-305 Bydgoszcz, Poland.

2) Warsaw University of Technology, Faculty of Materials Science, Wołoska 141, 02-507 Warszawa, Poland.

* Material contained in this article was presented at the Science and Technology Conference on "Polyurethanes 2019", Ustroń, Poland, 13-16 October 2019

**) Author for correspondence: milena.leszczynska.dokt@pw.edu.pl
} 
tych pianek, przeprowadzonym $\mathrm{w}$ firmie PLASTPUR, wykorzystano dwustrumieniową maszynę spieniającą firmy Hennecke.

Słowa kluczowe: porofory, addukty ditlenku węgla, pianki integralne, pianki poliuretanowe.

Foamed polyurethanes make up about $80 \%$ of the total production of this group of materials. In their production, blowing agents play an important role. The traditional chemical blowing agent is water known as $\mathrm{H}_{2} \mathrm{O} / \mathrm{CO}_{2}[1,2]$, because of the reaction of isocyanates with water, leading to formation of gaseous $\mathrm{CO}_{2}$, which, upon release forms a cellular foam structure. This process often causes an excessive increase of the reaction temperature and causes a decrease in the application properties of finished products. Its use is particularly dangerous in large-scale production of flexible block foam causing numerous self-ignition incidents of large production installations. This problem was solved only after the introduction of Liquid Carbon Dioxide (LCD) as a blowing agent. The use of LCD [2] as a foaming agent allowed to expand the range of flexible foams in the density range from $10-35 \mathrm{~kg} / \mathrm{m}^{3}$, while completely eliminating the possibility of self-ignition of the foam and, consequently, the entire production installation. This solution was optimal only for large installations, while other blowing agents were required for smaller installations. Methylene chloride (MC with b.p. $40^{\circ} \mathrm{C}$ ) turned out to be quite popular, which was used together with a small addition of water [1,3]. Methylene chloride was classified as an alternative foaming agent (ABA), but its properties, i.e. flammability and impact on health, did not allow for its widespread use [1]. Aliphatic hydrocarbons $\left(\mathrm{HC}\right.$ ) of the $n$-pentane type (b.p. $36.1^{\circ} \mathrm{C}$ ), iso-pentane (b.p. $27.8^{\circ} \mathrm{C}$ ) and cyclopentane (b.p. $39.3^{\circ} \mathrm{C}$ ) were another solution. The main purpose of HC are rigid foams [1, 4], but they are also used for other foams. Currently, the use of $\mathrm{HC}$ is still noticeable due to their low price, however, their strong flammability and explosion properties deter many investors. Based on existing experience, certain criteria for the selection of blowing agents in the synthesis of polyurethanes have been established.
Here are the most important of them: liquids with boiling points $10-40^{\circ} \mathrm{C}$, soluble and chemically inert to the raw materials involved in the foaming process, safe and friendly to people and the environment, non-flammable and non-explosive, with a low heat transfer coefficient. A group of the first generation of physical foaming agents called chlorofluorocarbons (CFCs), popularly known as freon F-11 in the processing of polyurethanes trichlorofluoromethane (CFC-11, b.p. $\left.23.8^{\circ} \mathrm{C}\right)$ turned out to be such a product that perfectly meets these characteristics. Due to these properties, freon F-11 has been used all over the world. However, freon destroys the ozone layer in the atmosphere (high value of ODP - Ozone Depletion Potential) and in accordance with the Montreal Protocol (1987), a decision was taken to finally withdraw it from use (1996). A similar fate befell the next group called hydrochlorofluorocarbons (HCFC) with the main representative of HCFC-141b (b.p. $32.0^{\circ} \mathrm{C}$ ) also due to the high value of GWP - Global Warming Potential [1], belonging to the group of greenhouse gases. This group of foaming agents was finally withdrawn in 2000-2003. In place of this group, the third generation of chlorine-free physical foaming agents was introduced - hydrofluorocarbons (HFCs) with known representatives of HFC-365mfc (b.p. $40.2^{\circ} \mathrm{C}$ ) and HFC-227ea (b.p. $16.4^{\circ} \mathrm{C}$ ) (Solvay) and HFC-245fa (Honeywell.b.p. $24.4^{\circ} \mathrm{C}$ ). In Europe, Solvay has particularly broadly developed the production and sale of HFC of its flagship product, Solkane $365 / 22793 / 7$, which is a mixture of 365 and 227 isomers in a 93/7 weight ratio [5, 6]. Similarly, widespread recognition among foam manufacturers was given to the competitive HFC-245fa [7]. Regardless of the qualitative improvements of physical foaming agents, the atmosphere was constantly monitored in accordance with the implementation of the Montreal Protocol principles and published for ongoing analysis of the effects of their impact $[8,9]$. The interpretation of these results

T a b l e 1. Description of blowing agents from the group of halogenated unsaturated hydrocarbons

\begin{tabular}{|c|c|c|c|c|}
\hline Structural formula & $\mathrm{CF}_{3}$ & $\mathrm{CF}_{3}$ & $\mu^{\mathrm{H}}$ & $\int_{c}^{\mathrm{H}}$ \\
\hline Name & $\begin{array}{l}\text { Trans-1-chloro-3,3,3- } \\
\text {-trifluoropropene }\end{array}$ & $\begin{array}{c}\text { Cis-1,1,1,4,4,4- } \\
\text {-heksafluoro-2-butene }\end{array}$ & $\begin{array}{l}\text { Trans-1-chloro-3,3,3- } \\
\text {-trifluoropropene }\end{array}$ & $\begin{array}{c}\text { Trans-1,3,3,3- } \\
\text {-tetrafluoropropene }\end{array}$ \\
\hline Name abbreviation & HFO-1233zd (E) & HFO-1336mzz (Z) & HFO-1233zd (E) & HFO-1234ze (E) \\
\hline Boiling point, ${ }^{\circ} \mathrm{C}$ & 18.6 & 33.4 & 19.0 & -19.0 \\
\hline $\begin{array}{l}\text { Supplier/Trade } \\
\text { name }\end{array}$ & $\begin{array}{c}\text { ARKEMA: } \\
\text { Forane FBA 1233zd }\end{array}$ & $\begin{array}{c}\text { Chemours: Opteon } 1100 \\
\text { DuPont: } \\
\text { Formacel FEA-1100 }\end{array}$ & $\begin{array}{l}\text { Honeywell: } \\
\text { Solstice LBA }\end{array}$ & $\begin{array}{c}\text { Honeywell: Solstice GBA } \\
\text { Applic. OCF, Aerosol } \\
\text { Propellant }\end{array}$ \\
\hline
\end{tabular}


was controversial, however, it was finally decided to eliminate HFC from polyurethane processing by 2023 , with the main reason being the value of the GWP $[10,11]$. In the years 2018/2019, a fourth group of foaming agents, halogenated unsaturated hydrocarbons (HFO/HCFO), having low ODP values -0 and GWP of about 1 were introduced into industrial practice. The most known blowing agents from this group are Soltice LBA (Honeywell) with the chemical name trans 1-chloro-3,3.3-trifluoropropene with the formula $(E) \mathrm{CF}_{3}-\mathrm{CH}=\mathrm{CHCl}$, classified as a nonflammable compound with a boiling point of $19^{\circ} \mathrm{C}$ [12]. Another blowing agent from this group is the Arkema product with the trade name Forane FBA 1233zd, with the chemical name trans 1-chloro-3,3,3-trifluoropropene, formula $(E) \mathrm{CHCl}=\mathrm{CHCF}_{3}$ and boiling point $18.6^{\circ} \mathrm{C}$ [13] Another commercially available HFO hydrocarbon blowing agent is a DuPont product called FEA 1100 (trade name Formacel 1100) with the formula $\mathrm{CF}_{3}-\mathrm{CH}=\mathrm{CHCF}_{3}$ and boiling point $33.4^{\circ} \mathrm{C}$ [14]. The distribution of this product under the name Opteon 1100 [15] has now been taken over by Chemours. Detailed data on physical foaming agents present on the market are summarized in the Table 1.

Currently, these agents and HFCs are widely used. In a few years, the first results of comprehensive foam testing with these blowing agents will be after many years of practical testing. The initial assessment of their recipients is positive. As a result of using these blowing agents, the recipients receive systems that do not pose processing problems yet. However, in new applications, problems related to the application of HFO agents have been observed, resulting from the deformation of surfactants and catalysts, which results in a change in processing parameters and properties of the final product. The problem increases with the extension of storage times for polyol mixtures containing these blowing agents, even leading to the phenomenon of collapse (foam falling) [16] and the properties of the final product.

Based on these observations, it was found that additional studies on the stability of mixtures during storage with these agents were necessary. Taking into account the above reservations, works referring to traditional foaming with the use of water as a chemical blowing agent $\mathrm{H}_{2} \mathrm{O} / \mathrm{CO}_{2}$ are still being conducted [17-20]. The Canadian company Icynene Europe mainly offers spray foams for the construction industry based on the $\mathrm{H}_{2} \mathrm{O} / \mathrm{CO}_{2}$ blowing agent under the brand name $\mathrm{H}_{2}$ Foam [21].

The 1-4 generations of physical blowing agents presented above cover their applications not only for the production of polyurethanes, but also for other industrial sectors such as refrigeration (domestic, industrial, transport), air conditioning (automotive, industrial), transmission of energy factors (heat pumps), products of the type spray (cosmetics).

Therefore, they are produced in a large scale and these substances have become a serious global problem related to the climate change. The problem of using these means is not only their direct use, but also their behavior during the use of products, in the recycling processes and utilization of the equipment in which they were used. Due to the importance of the problem, an UNEP (United Nations Environment Program) office was established at the UN to monitor the application and utilization of these funds in all areas of the economy around the world.

Published UNEP reports $[1,10]$ contain detailed statements and recommendations for the coming years. SNAP (Significant New Alternatives Policy) and US EPA (Environmental Protection Agency) were established to monitor the impact of these blowing agents and accreditation of new solutions. The cited data shows that of all products included in the foam formulations, the most changes were observed in physical foaming agents. Four generations of funds have been replaced over 60 years. This unstable situation leads to the search for and development of alternative foaming agents for use, especially in the production of niche products. These alternative blowing agents (ABA) include: methylene chloride, acetone, low-boiling ethers, formic acid (which produces a foaming mixture $\left(\mathrm{CO}+\mathrm{CO}_{2}\right)$, methylal (dimethoxymethane), methyl formate, methyl acetate. Great attention is still devoted to the use of carbon dioxide in various compounds in the form of gas (gas carbon dioxide - GCD) [22], liquid (liquid carbon dioxide - LCD) [23], in supercritical state $\left(\mathrm{SC} \mathrm{CO}_{2}\right)$ [24]. However, their practical application requires the use of pressure equipment and advanced technology. $\mathrm{CO}_{2}$ adducts with aliphatic amines as foaming agents have proved to be interesting. The first studies concerned $\mathrm{CO}_{2}$ adducts with secondary amines together with tertiary amines [25]. However, the main purpose of their use was to reduce the reactivity of the amines during foaming. Alkanolamines with carbon dioxide were another material [26-29]. The process of obtaining adducts was easier due to smaller thermal effects during their synthesis, which limited the possibility of their decomposition.

Quite advanced work was carried out on the development of adducts with primary amines and aminoethanols. Their usefulness was verified on the technical installation while receiving integral foam for the production of the steering wheel [30]. Interesting results were obtained using $\mathrm{CO}_{2}$ adducts with polyethyleneimines grafted with $\mathrm{C}_{4}-\mathrm{C}_{16}$ alkyl side chains.

Adducts containing 13.8 wt \% carbon dioxide that were released in the foaming process were obtained [31]. A broad review of foaming agents also taking into account carbon dioxide adducts was presented by Wiankowski and co-authors [32]. The analyzes presented in the article confirm the possibilities and the need for further work on blowing agents for polyurethane foams, because of the arising question: Will the fourth generation of foaming agents used in industrial practice prove themselves after many years of using them in practice in extremely drastic conditions?. The authors of the article made another attempt to develop carbon dioxide adducts to expand the range of blowing agents. In the first stage of work, they 
verified their usefulness in the process of manufacturing niche products. Preparation of $\mathrm{CO}_{2}$ adducts with amines, which have primary, secondary and tertiary nitrogen atoms in one molecule was developed. This gives the possibility to use agents that are also regulators of the synthesis parameters (start, rise and gelling times) and limits or eliminates the use of organometallic compounds as gelling additives [33].

\section{EXPERIMENTAL PART}

The experimental part includes three stages of work: preparation of $\mathrm{CO}_{2}$ adducts with amines, preparation of isocyanate prepolymers, preparation of integral foams on a laboratory and industrial scale.

\section{Materials}

\section{Polyols}

Rokopol DE 4020 - polyetherol based on propylene oxide and ethylene glycol, with a hydroxyl number $(\mathrm{LOH})$ $29.5 \mathrm{mgKOH} / \mathrm{g}$, molecular weight $4000 \mathrm{~g} / \mathrm{mol}$, functionality 2 (PCC Rokita);

Rokopol M 6000 - polyetherol based on propylene oxide/ethylene/glycerine; $\mathrm{LOH}=28 \mathrm{mgKOH} / \mathrm{g}$, molecular weight $6000 \mathrm{~g} / \mathrm{mol}$, tri-functional (PCC Rokita);

Desmophen 7619W - polymeric polyetherol which is a mixture of reactive polyetherol and ground polyurea, with a $\mathrm{LOH}=28 \mathrm{mgKOH} / \mathrm{g}$, viscosity approx. $4000 \mathrm{mPa} \cdot \mathrm{s}$ at $25^{\circ} \mathrm{C}$ (Covestro A.G).

\section{Extension and cross-linking agents}

Monoethylene glycol (MEG) - acts as a chain extender and adduct component (Z.Ch. Organika S.A. Łódź);

Triethanolamine (TELA) - acts as a crosslinker and adduct component, molecular weight $149 \mathrm{~g} / \mathrm{mol}$ (PCC Rokita).

\section{Catalyst}

Jeffcat ZF-10 - reactive amine catalyst (Huntsman);
Dabco NE 300 - amine catalyst (Air Products);

Jeffcat DMDPTA - N,N-dimethyl dipropylene triamine $\left(\mathrm{CH}_{3}\right)_{2} \mathrm{~N}\left(\mathrm{CH}_{2}\right)_{3} \mathrm{NH}(\mathrm{CH})_{2} \mathrm{NH}_{3}$, molecular weight $159.3 \mathrm{~g} / \mathrm{mol}$ (Huntsman);

Dabco NE 1070 - N-(3-dimethylamino) polyurea, $\mathrm{H}_{2} \mathrm{NC}(\mathrm{O}) \mathrm{NH}\left(\mathrm{CH}_{2}\right)_{3} \mathrm{~N}\left(\mathrm{CH}_{3}\right)_{2}$, molecular weight $145 \mathrm{~g} / \mathrm{mol}$ (Air Products);

1-(2-aminoethyl) piperazine (AEP) $\mathrm{HN}\left(\mathrm{CH}_{2} \mathrm{CH}_{2}\right)_{2} \mathrm{~N}\left(\mathrm{CH}_{2}\right)_{2} \mathrm{NH}_{2}$, molecular weight $129.2 \mathrm{~g} / \mathrm{mol}$ (Sigma-Aldrich);

Dabco MB 20 - bismuth-based gel catalyst;

DBTDL - tin(IV) dibutyldilaurate, incl. tin(IV) 18-19 wt \% (Sigma-Aldrich).

Dabco MB 20 and DBTDL were used in the form of: $25 \mathrm{wt} \%$ solution of DABCO MB 20 in Rokopol M 6000 and 25 wt \% solution of DBTDL in Rokopol M 6000.

\section{Surfactants}

Tegostab B 4900 (Evonik);

Dabco DC 2525 (Air Products).

\section{Isocyanate}

Ongronate 3800, modified 4.4-methylenediphenylisocyanate (MDI) containing $28 \mathrm{wt} \% \mathrm{NCO}$ groups (Borsodchem, ON3800).

\section{Blowing agent}

Carbon dioxide gas, type 4.5 (Linde Gaz).

\section{Preparation of carbon dioxide amine adducts}

Carbon dioxide gas was dosed into the prepared solution of 25-50 wt \% amine in monoethylene glycol (MEG) or into the triethanolamine (TELA) to obtain a constant mass value. Saturation was carried out at a temperature of $10-12^{\circ} \mathrm{C}$, in a water-cooled tubular reactor equipped with a speed-controlled stirrer. Gaseous $\mathrm{CO}_{2}$ was fed under the agitator disk with a glass tube terminated with a $1.5 \mathrm{~mm}$ diameter hole. The characteristics of the adducts produced are presented in Table 2.

$\mathrm{T}$ a b 1 e 2. Description and characteristics of produced adducts

\begin{tabular}{|c|c|c|c|c|c|c|}
\hline $\begin{array}{l}\text { No. } \\
\text { adduct }\end{array}$ & $\begin{array}{c}\text { Adduct } \\
\text { composition }\end{array}$ & $\begin{array}{c}\text { Content amines in } \\
\text { solution } \\
\text { wt } \%\end{array}$ & $\begin{array}{l}\mathrm{CO}_{2} \text { content } \\
\text { in the final } \\
\text { solution } \\
\text { wt } \%\end{array}$ & $\begin{array}{c}\mathrm{CO}_{2} \text { absorption } \\
\text { per } 100 \mathrm{~g} \text { of amine } \\
\text { wt } \%\end{array}$ & $\begin{array}{c}\text { Theoretical } \mathrm{CO}_{2} \\
\text { absorption } \\
\text { per } 100 \mathrm{~g} \text { of amine } \\
\text { wt } \%\end{array}$ & $\begin{array}{c}\text { Degree of } \\
\text { amine saturation } \\
\mathrm{CO}_{2} \%\end{array}$ \\
\hline Add. 1 & MEG/DMDPTA & 25 & 13.2 & 48 & 55.2 & 86.9 \\
\hline Add. 2 & MEG/DMDPTA & 40 & 14.7 & 43 & 55.2 & 78.1 \\
\hline Add. 3 & MEG/DMDPTA & 50 & 15.2 & 34 & 55.2 & 61.6 \\
\hline Add. 4 & MEG/NE 1070 & 25 & 5.0 & 21 & 30.3 & 16.5 \\
\hline Add. 5 & MEG/AEP & 25 & 10.5 & 47 & 68.1 & 68.8 \\
\hline Add. 6 & TELA/DMDPTA & 40 & 16.2 & 48 & 55.2 & 86.9 \\
\hline
\end{tabular}


$\mathrm{T}$ a b l e 3. Description and characteristics of prepared isocyanate prepolymers

\begin{tabular}{|c|c|c|c|c|c|}
\hline No. prepolymer & $\begin{array}{l}\text { Prepolymer } \\
\text { composition }\end{array}$ & $\begin{array}{c}\text { Quantity } \\
\text { ON } 3800 \\
\text { g }\end{array}$ & $\begin{array}{l}\text { Quantity } \\
\text { polyol } \\
\text { g }\end{array}$ & $\begin{array}{l}\text { Content of NCO } \\
\text { groups in the } \\
\text { prepolymer, wt \% }\end{array}$ & $\begin{array}{c}\text { Viscosity at } 25^{\circ} \mathrm{C} \\
\mathrm{mPa} \cdot \mathrm{s}\end{array}$ \\
\hline P1 & ON 3800/DE 4020 & 500 & 212 & $19.5 \pm 0.5$ & 1500 \\
\hline P2 & ON 3800/M 6000 & 500 & 213 & $19.2 \pm 0.5$ & 1600 \\
\hline
\end{tabular}

\section{Preparation of isocyanate prepolymers}

Currently, polyurethane integral foams are produced using physical blowing agents in quantities of $5-30 \mathrm{wt} \%$ of the total polyol component. These agents dilute the foaming mixture, improving mixing conditions, and lowering the reaction temperature. Elimination of these agents may cause difficulties in obtaining the expected effects, mainly due to the increased reaction speed and the possibility of excessive temperature increase. In order to avoid these effects, a variant of using MDI prepolymers with a reduced content of isocyanate groups to $19-21 \mathrm{wt} \%$ seemed to meet the above assumptions. Preparation of prepolymers from isocyanate was performed by a traditional method. The desired amount of isocyanate was placed in a $500 \mathrm{~cm}^{3}$ three-necked flask equipped with a stirrer, reflux condenser, thermometer and dropping funnel and heated to $50^{\circ} \mathrm{C}$. In the next stage, a specific amount of polyol was slowly metered in. The reaction was carried out under an atmosphere of dried nitrogen. As a result of the reaction, the temperature gradually increased to $70^{\circ} \mathrm{C}$. The polyol addition was continued while maintaining the temperature at $70-80^{\circ} \mathrm{C}$. After the required amount of polyol was introduced, the mixture was further held at this temperature for two hours. After cooling and storage for several hours under normal conditions, the fluidity, appearance (sediment content) and then the content of isocyanate groups was assessed. The basic criterion for the usefulness of prepolymers was to obtain a liquid prepolymer at room temperature for six months and a maximum viscosity of $2000 \mathrm{mPa} \cdot \mathrm{s}$. Based on this method, many prepolymers were obtained and tested. The most favorable properties were obtained when Rokopols DE 4020 and M 6000 were used in their preparation. Both prepared prepolymers were in liquid form for more than 6 months. The description of the prepolymers are shown in Table 3.

\section{Preparation of integral foams on a laboratory scale}

A series of reference foams with an $\mathrm{H}_{2} \mathrm{O} / \mathrm{CO}_{2}$ blowing agent, marked with the symbol R1-R4, and a series of foams with the addition of $\mathrm{CO}_{2} /$ amine adducts marked with W1-W9 were produced. Both groups of integral foams were obtained by foaming two components $\mathrm{A}$ and $\mathrm{B}$.

$\mathrm{T}$ a $\mathrm{b} l$ e 4 . Recipes of manufactured integral foams and their selected properties

\begin{tabular}{|c|c|c|c|c|c|c|c|c|c|c|c|c|c|c|}
\hline \multirow{2}{*}{ No. } & \multirow{2}{*}{ Name } & \multicolumn{13}{|c|}{ Amount of raw materials used, part wt } \\
\hline & & R1 & W1 & $\mathrm{R} 2$ & W2 & R3 & W3 & $\mathrm{R} 4$ & W4 & W5 & W6 & W7 & W8 & W9 \\
\hline 1 & MEG & 8.4 & 6.3 & 8.4 & & 8.4 & & 5.0 & 5.0 & & 2.3 & 4.3 & & \\
\hline 2 & M 6000 & 41.4 & 41.4 & 41.4 & 41.4 & 41.4 & 41.4 & 41.4 & 55.2 & 41.4 & 41.4 & 41.4 & 41.4 & 41.4 \\
\hline 3 & D7619W & 27.6 & 27.6 & 27.6 & 27.6 & 27.6 & 27.6 & 26.6 & 13.8 & 27.6 & 27.6 & 27.6 & 27.6 & 27.6 \\
\hline 4 & ZF-10 & 0.06 & 0.06 & & & 0.06 & 0.06 & 0.06 & 0.06 & 0.06 & & 0.10 & 0.10 & 0.10 \\
\hline 5 & NE 300 & & & 0.06 & 0.06 & & & & & & 0.06 & & & \\
\hline 6 & MB 20 & & & 0.8 & 0.6 & 0.8 & & 0.8 & 0.6 & & 0.6 & & & \\
\hline 7 & DBTDL & 0.02 & 0.015 & & & & 0.015 & & & 0.01 & & & & \\
\hline 8 & В 4900 & 0.3 & & & & & 0.3 & & & 0.3 & & & 0.3 & 0.3 \\
\hline 9 & DC 2525 & & & 0.3 & 0.3 & 0.3 & & 0.3 & & & 0.3 & 0.2 & & \\
\hline 10 & Add. 1 & & 5.5 & & 10.0 & & 5.1 & & 5.7 & & & & 6.0 & 5.0 \\
\hline 11 & Add. 4 & & & & & & & & & 5.1 & & & 6.0 & 5.0 \\
\hline 12 & Add. 5 & & & & & & & & & & 8.8 & 6.0 & & \\
\hline 13 & Water & 0.1 & 0.1 & 0.2 & 0.2 & 0.3 & 0.3 & 0.6 & 0.6 & 0.3 & 0.2 & 0.1 & 0.1 & 0.2 \\
\hline 14 & $I_{\mathrm{NCO}} \mathrm{P} 1$ & 1.0 & 1.0 & 1.0 & 1.0 & 1.0 & 1.0 & 1.0 & & 1.0 & 1.0 & & 1.0 & \\
\hline 15 & $I_{\mathrm{NCO}} \mathrm{P} 2$ & & & & & & & & 1.0 & & & 1.0 & & 1.0 \\
\hline & & & & & electe & rope & $\mathrm{s}$ of int & $\mathrm{ral} \mathrm{fo}$ & & & & & & \\
\hline & $\begin{array}{l}\text { nsity } \\
/ \mathrm{m}^{3}\end{array}$ & 350 & 221 & 301 & 191 & 287 & 157 & 208 & 132 & 147 & 231 & 180 & 128 & 130 \\
\hline & $\begin{array}{l}\text { dness } \\
\text { hA }\end{array}$ & 46 & 40 & 46 & 23 & 38 & 8 & 15 & 15 & 10 & 20 & 10 & 12 & 10 \\
\hline
\end{tabular}


T a b l e 5. Characteristics of raw materials for the production of integral foams on the industrial scale

\begin{tabular}{l|c|c|c}
\hline \multicolumn{1}{c|}{ Name } & Units & Component A + amine adduct & Component B \\
\hline Density at $25^{\circ} \mathrm{C}$ & $\mathrm{g} / \mathrm{cm}^{3}$ & 1.05 & 1.25 \\
Viscosity at $25^{\circ} \mathrm{C}$ & $\mathrm{mP} \cdot \mathrm{s}$ & 840 & 1600 \\
NCO content & $\mathrm{wt} \%$ & - & 19.2 \\
$\begin{array}{l}\text { The content of reactive groups in polyol } \\
\text { stream expressed as LOH value }\end{array}$ & $\mathrm{mgKOH} / \mathrm{g}$ & 218.5 & - \\
\hline
\end{tabular}

$\mathrm{T}$ a b 1 e 6. Integral foams on an industrial scale using $\mathrm{CO}_{2}$ adduct

\begin{tabular}{c|l|c|c}
\hline No. & \multicolumn{1}{|c|}{ Name } & Density, $\mathrm{kg} / \mathrm{m}^{3}$ & Hardness, ${ }^{\circ}$ ShA \\
\hline 1 & Test foam - free growth & 190 & 22 \\
2 & Molded test foam $\left(1.5 \mathrm{dm}^{3}\right)$ & 280 & 27 \\
3 & Molded test foam $\left(1.5 \mathrm{dm}^{3}\right)$ & 294 & 35 \\
4 & Molded foam - chair & - & 38 \\
\hline
\end{tabular}

Component A was prepared by mixing for 5 min: polyols, foaming agents (adducts, water), surfactants and catalysts with a stirrer speed of $3000 \mathrm{rpm}$. In next stage the P1 or P2 prepolymer (in amounts corresponding to the NCO index about 1.0) was poured into component $\mathrm{A}$, and the mixture was mixed again with a high-speed mixer for 6 seconds and quickly poured into an open polypropylene container $\left(1.5 \mathrm{dm}^{3}\right)$ and mainly into a metal test mold $\left(1.5 \mathrm{dm}^{3}\right)$. After 5 minutes, the foam was demolded and then baked for an additional 2 hours at $70^{\circ} \mathrm{C}$. After 3 days of seasoning at room temperature, the foams were analyzed. The following were assessed: surface quality (number of pits), density, cell regularity, hardness. The recipes of manufactured integral foams are summarized in Table 4.

\section{Preparation of integral foams on an industrial scale}

On an industrial scale, integral foams were made at PLASTPUR (Bydgoszcz) on the Hennecke double-stream dispensing machine. The polyol stream was prepared by mixing component $\mathrm{A}$ (previously prepared in laboratory scale) with amine adduct (FAMPUR know-how) in a 9:1 weight ratio. The isocyanate stream (B) was used as P2 prepolymer. The substrates were mixed at a ratio of: (A+ amine adduct) $: \mathrm{B}=100: 96$ at $I_{\mathrm{NCO}}=1.1$ (Table 5). Foams were made at the following: dosing pressure $18.0 \mathrm{MPa}$, raw material temperature $24^{\circ} \mathrm{C}$, mold temperature $50^{\circ} \mathrm{C}$, demolded time 6 min.

Technical tests were performed on a high-pressure machine dispensing raw materials in two streams. The polyol component was prepared in the working tank of the device by mixing previously prepared component $\mathrm{A}$ and the amine adduct. The mixed polyol stream was fed together with the prepolymer to the dosing head. Before production with using industrial molds, laboratory tests were performed and after positive assessment, target products using the industrial molds (seats for office chairs) were made. The determined synthesis parameters for foam with free growth are: start time $-5 \mathrm{~s}$, rise time $135 \mathrm{~s}$, gel time $-185 \mathrm{~s}$. The results of the selected product properties are presented in Table 6 .

\section{Methods of testing}

The following determinations were used to characterize the adducts:

$m \mathrm{CO}_{2}$ weight gain in the saturation process $(\mathrm{g})$ until constant weight was achieved.

The $\mathrm{CO}_{2}$ content in the solution was calculated according to formula:

$$
\frac{m \mathrm{CO}_{2}}{m \mathrm{MEG}+m \mathrm{DMDPTA}+m \mathrm{NE} 1070+m \mathrm{CO}_{2}} \cdot 100 \%
$$

Real absorption $-m \mathrm{CO}_{2} / 100 \mathrm{~g}$ of amine used.

Theoretical absorption $\mathrm{CO}_{2}$ as calculated according to formula:

$$
\frac{\mathrm{M}_{w} \mathrm{CO}_{2}}{\text { Chemical equivalent of the amine used }} \cdot 100 \%
$$

where: $M_{w}$ - molecular weight of $\mathrm{CO}_{2}$.

The degree of saturation $\mathrm{CO}_{2}$ was calculated according to formula:

$$
\frac{\text { Real absorption }}{\text { Theoretical absorption }} \cdot 100 \%
$$

Mass measurements were made with the help of a Radwag analytical balance with accurate reading up to $0.001 \mathrm{~g}$.

The content of NCO groups in prepolymers was determined by inverse potentiometric titration (Mettler Toledo) according to ISO 14896.

The apparent density of the foam together with the skin was determined by the method of ISO 845 . Mass measurements were made with the help of a Radwag 
analytical balance with accurate reading up to $0.001 \mathrm{~g}$. Linear dimensions were measured with a caliper with a precision accuracy of $\pm 0.01 \mathrm{~mm}$. Measurements were made at room temperature.

The regularity of the cells in the products was assessed visually by observing their cross-section.

Hardness ( ${ }^{\circ} \mathrm{Sh} A$ ) was determined according to PN ISO 868, using a Shore Durometer Hardness Tester.

The density of the components was measured with a $25 \mathrm{~mm}$ pycnometer.

The viscosity at $25^{\circ} \mathrm{C}$ was measured with a Höppler viscometer.

\section{RESULTS AND DISCUSSION}

\section{Amine dioxide adducts}

As the main part of the study the series of $\mathrm{CO}_{2}$ adducts with amines were made and the characteristics of these adducts were presented in Table 2. Amines were used to make the adducts, which are usually used as reactive additives to regulate foaming parameters such as start, rise and gelling times. The DMDPTA amine and AEP are known for their use mainly as a foaming and partly as gelling catalysts. In contrast, the Dabco NE1070 amine is known as a strong organic catalyst for gelling and partly foaming. At this stage of research on the process of producing adducts, complete saturation of amines with $\mathrm{CO}_{2}$ could not be achieved. The most favorable absorption result of $86.9 \%$ was obtained for Add. 1 prepared from the MEG/DMDPTA mixture. So, in the case of the MEG/DMDPTA adduct, the influence of amine content on the amount of $\mathrm{CO}_{2}$ absorption in the solution and the degree of $\mathrm{CO}_{2}$ supersaturation was assessed (Fig. 1).

Analysis of Fig. 1 shows that with a significant increase of the proportion of amine in the mixture with MEG (from $25 \mathrm{wt} \%$ to $50 \mathrm{wt} \%$ at Add. 3) only a slight increase of $\mathrm{CO}_{2}$ absorption (from $13.2 \mathrm{wt} \%$ to $15 \mathrm{wt} \%$ at Add. 3) and a significant reduction $\mathrm{CO}_{2}$ saturation rate (from $86.9 \%$

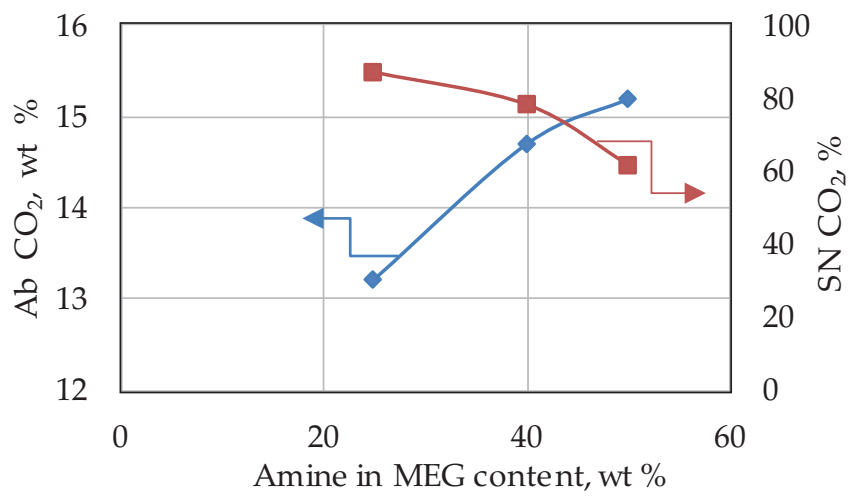

Fig. 1. Impact of DMDPTA amine content in MEG on the $\mathrm{CO}_{2}$ content in the solution $(\mathrm{Ab} \mathrm{CO})$ and the degree of solution supersaturation by carbon dioxide $\left(\mathrm{SN} \mathrm{CO}_{2}\right)$ to $61.6 \%$ at Add. 3) were observed. These results indicate that the use of amines in amount of $25 \mathrm{wt} \%$ is preferred for the configuration DMDPTA/MEG. Therefore, the further adducts with other catalysts (Dabco NE1070 and AEP) were made using concentration of $25 \mathrm{wt} \%$ amine in MEG, too. As a result of this suggestion, the adducts with different $\mathrm{CO}_{2}$ absorption and various degree of supersaturation were obtained.

The lowest values have the adduct based on Dabco NE1070 (Fig. 2), which is largely associated with the structure of the amine.

Based on these results, adducts containing 25 wt \% of amines in a mixture with MEG were selected for the production of integral foams. In addition, at higher concentrations of amine/MEG systems, the viscosity of the mixture increases, which hinders absorption efficiency and increases the prices of adducts in relation to the blowing agents available on the market.

US patent [28] describes the adducts of primary and secondary amines with $\mathrm{CO}_{2}$. Solutions with a saturation of approx. $10.2 \mathrm{wt} \%$ were obtained. These solutions were used to obtain sprayed rigid insulating foams as thermal insulation in construction. These adducts were used in a mixture with water and HCFC-141b, obtaining foams with a core density of $31 \mathrm{~kg} / \mathrm{m}^{3}$.

In the presented article, mixtures of adducts with water were also used on a laboratory scale to obtain satisfactory integral foams. While continuing this work, it is anticipated to use mixtures of these adducts with water and HFO hydrocarbons for some applications.

The US patent [29] describes the $\mathrm{CO}_{2}$ adducts with alkanolamines in solutions of monoethylene glycol and 1,4-butanediol. These adducts contained $12.4 \mathrm{wt} \% \mathrm{CO}_{2}$. The adducts of primary amines and ethanolamines from $\mathrm{CO}_{2}$ described in the patent [30] were obtained by saturating $\mathrm{CO}_{2}$ gas with a $50 \mathrm{wt} \%$ solution of amine in glycol. The resulting products contained 11.8-15.6 wt \% $\mathrm{CO}_{2}$, they were used to produce steering wheels with a hardness of $57^{\circ} \mathrm{ShA}$.

The long-term work of the Long Y. team and colleagues also deserve attention [34-36]. These works concerned the

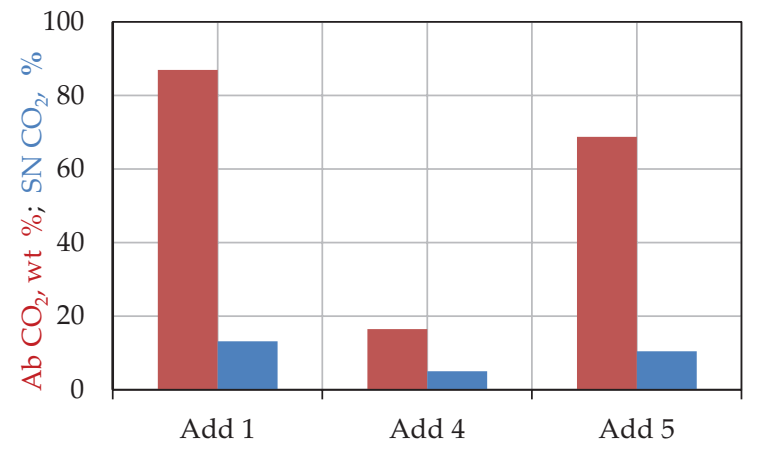

Fig. 2. $\mathrm{CO}_{2}$ absorption and degree of supersaturation in adducts made at $25 \mathrm{wt} \%$ of amines in a mixture with MEG 
research on the impact of polyethyleneimine (PEI) grafting parameters, with various hydrophobic side chains, on the amount of $\mathrm{CO}_{2}$ gas absorption. As a result of these works, adducts containing from $15-33$ wt $\%$ of $\mathrm{CO}_{2}$ were obtained. However, the results presented in Long Y. et al. [36] indicate that adducts containing $12.8 \mathrm{wt} \%$ of $\mathrm{CO}_{2}$ have chances for technical applications. Adducts produced under this article: Add. 1, Add. 2, Add. 3, Add. 5 and Add. 6 showed a degree of saturation from approx. $62 \%$ to $87 \% \mathrm{CO}_{2}$ relative to the amine used, which indicates the possibility of further improvement of the $\mathrm{CO}_{2}$ absorption process.

\section{Isocyanate prepolymers}

For the production of integral foams, the two types of prepolymers made of ON3800 isocyanate and two types of polyols of Rokopol DE 4020 and Rokopol M 6000 were proposed. The results of prepolymers characteristics were presented in Table 3.

These prepolymers met the assumed selection criteria in the range of several months of stability as liquid and value of the viscosity. Previous attempts to obtain prepolymers from other raw materials did not achieve these assumed parameters. The following raw materials were tested: isocyanates ON3000, 3600, 4040 (from Borsodchem) and polyols: DPG (dipropylene glycol) Rokopol D 2002 (PCC Rokita), PTMG [poly(tetra-methylene ether glycol)], Daltocel F 548 (Huntsman).

\section{Integral foams prepared on a laboratory scale}

The results presented in Table 4 confirm the possibility of replacing the currently used physical blowing agents with amine adducts. The use of $\mathrm{CO}_{2}$ adducts with the DMDPTA in W1, W2, W3 and W4 systems allowed to obtain integral foams with significantly lower density and hardness, compared to the reference foam systems R1, R2, R3 and R4, respectively. In the W8 and W9 experiments, the two types of adducts were used the first as the DMDPTA/MEG and the second DABCO NE1070/MEG systems. Thanks to their combined application, favorable foaming parameters for integral foams without additional gelation agents were obtained [22]. The elimination of organometallic gelling additives allows the implementation of the European Commission Directive No. 276/2010 changing the classification of DBTDL from harmful to poisonous while reducing the permissible tin (IV) content in the product mass to the level of $0.1 \%$ by mass. The W8 and W9 foams made with the use of adducts have about $80 \%$ lower density and their hardness decreases by $20 \%$ and $33 \%$, respectively compared to R4 foam. In addition, the amines used in the adducts have isocyanate-reactive groups and are incorporated into the polymer chain, which significantly reduces the TVOC (Total Volatile Organic Compounds) values of the finished product [30].
In addition, the W2, W3, W4, W6, W9 tests indicate the regulation possibility of density and hardness by selection of mutual amounts of water and amine adducts. Probably, due to the use of prepolymers, no noticeable negative thermal effects were noted (pitting, blows, disruption of the cell structure, too high foaming rate, etc.). Obtaining positive results in laboratory tests allowed to carry out an attempt to obtain integral foam on an industrial scale.

\section{Integral foams prepared on an industrial scale}

The results of integral foams characteristics were presented in the Table 6. Tests carried out on an industrial scale confirmed the possibility of target use of amine adducts with $\mathrm{CO}_{2}$ as blowing agents for polyurethane integral foam. Industrial tests were made courtesy of PLASTPUR, Bydgoszcz. A short time to carry out tests on an industrial scale $(8 \mathrm{~h})$ did not allow for additional work on the selection of adduct composition and optimization of processing parameters. Production tests were carried out without any modification of the machine, molds and separation means (registered name). These tests confirmed the possibility of using existing foaming equipment to manufacture products using the developed $\mathrm{CO}_{2}$ amine adducts.

When the apparatus had been emptied, normal production of integral foam was started within 30 minutes.

The adducts described in the patent [29] were used for the production of integral foams, which with a free growth had a density of $220-330 \mathrm{~kg} / \mathrm{m}^{3}$.

In the industrial research presented in the presented article, foams had a comparable density of $190 \mathrm{~kg} / \mathrm{m}^{3}$.

The adducts described in the patent [30] were used in industrial practice for the production of steering wheels, obtaining integral foam with a hardness of $57^{\circ} \mathrm{ShA}$.

Integral foams manufactured by PLASTPUR as a part of a furniture chair seat with a hardness of $38^{\circ} \mathrm{ShA}$, confirm the wide possibility of using amine adducts from $\mathrm{CO}_{2}$ to produce integral foams in various applications.

\section{CONCLUSIONS}

As a result of the research, several types of amine $\mathrm{CO}_{2}$ adducts were developed. The original adduct model from amine and $\mathrm{CO}_{2}$ catalysts was developed for use as a blowing agents in the production of integral foams. An additional advantage of these adducts is the ability to eliminate organometallic gel catalysts. In order to be able to manufacture the developed adducts for the production of integral foams recipes and process parameters for the production of isocyanate prepolymers were developed. Using a series of isocyanate adducts and prepolymers, a series of integral foams was produced on a laboratory scale. The results of these tests indicate the possibility of adjusting the density (in the range of 128$221 \mathrm{~kg} / \mathrm{m}^{3}$ ) and hardness (in the range of $8-40^{\circ} \mathrm{ShA}$ ) of 
integral foams by selecting mutual amounts of water and developed amine adducts. Based on the results of these tests, amine adducts, prepolymers and a recipe for the production of integral foams on an industrial scale were proposed. Products manufactured on an industrial scale meet the requirements for the production of integral foam products (190-294 kg/m³ at hardness $22-38^{\circ} \mathrm{ShA}$ ). During further work on the developed group of adducts, it is advisable to carry out research aimed at increasing the degree of $\mathrm{CO}_{2}$ absorption and work on new engineering solutions for the absorption equipment, as well as on new reactive process solvents. Preliminary tests carried out by the authors of the article on the use of the developed $\mathrm{CO}_{2}$ adducts for other types of polyurethane foams indicate that they can also be useful in their production, in particular for the production of rigid flood and spray foams.

Based on the review of recent research [16] it is recommended to intensify the control activity in the cases using the 4th generation of physical blowing agents for new applications. Particular attention should be paid to new applications and new foam formulations due to the potential for destruction of catalysts and surfactants.

\section{ACKNOWLEDGMENTS}

The authors express great gratitude and thanks to the PLASTPUR company in Bydgoszcz for taking the risk and creating the possibility of conducting production tests, great friendly help and advice of employees during foaming.

\section{REFERENCES}

[1] UNEP-2002 Report of the Rigid and Flexible Foams, Technical Options Committee, 2002, pp. A $7-A_{1} 12$.

[2] Prociak A., Rokicki G., Ryszkowska J.: „Materiały poliuretanowe", Wydawnictwo Naukowe PWN, Warszawa 2014.

[3] Brumner K., Schrock A.K.: “Technical Advances in the Elimination of Blowing Agents in Flexible Slabstock System", Conference Proceedings, Utech '92, Dow Chemical Europe 1992, 92, 194.

[4] Kurańska M., Prociak A., Michałowski S. et al.: Polimery 2018, 63, 672. https://doi.org/10.14314/polimery.2018.10.2

[5] https://www.solvay.us/en/binaries/P19465-USA_ CN_EN-237819.pdf

[6] http://www.tecnologiademateriais.com.br/mt/2010/ cobertura_paineis/isolamento/apresentacoes/solvay. pdf

[7] Williams D., Bogdan M.: "Performance of HFC-245fa in Integral Skin Foam Application", Conference Proceedings, Polyurethanes 2000, p. 250.

[8] Vollmer M.K., Reimann S., Folini D. et al.: Geophysical Research Letters 2006, 33 (20), L20806. https://doi.org/10.1029/2006GL026763

[9] Stemmler K., Folini D., Ubl S. et al.: Environmental Science \& Technology 2007, 41 (4), 1145.

\section{https://doi.org/10.1021/es061298h}

[10] UNEP-May 2018. Progress Report 2018, V3, pp. 5-9. https://www.unenvironment.org/annualreport/2018/ index.php

[11] Regulation (EU) No 517/2014 of the European Parliament and of the Council of 16 April 2014 on Fluorinated Greenhouse Gases and Repealing Regulation (EC) No 842/2006.

https://www.eea.europa.eu/policy-documents/regulation-eu-no-517-2014

[12] Honeywell Solstice 1233zd(E), Honeywell 2013.

https://static 1 .squarespace.com/static/59cce 8 bba 9 db 0941 ea 92 e $75 f / t / 59 d 2598$ e914e6bc265306b3b/1506957710989/honeywell-solstice-LBA-technical-brochure.pdf

[13] Fluorochemicals-Forane FBA 1233zd Blowing AgentTechnical Profile, Arkema Inc. 2017.

https://www.arkema.com/en/products/product-finder/product-viewer/Forane-FBA-1233zd-foamblowing-agent/?t=4

[14] DuPont receives US EPA approval for Formacel 1100 foam expansion agent, 2014.

https://www.chemicals-technology.com/news/newsdupont-receives-us-epa-approval-for-formacel-1100foam-expansion-agent-4413936

[15] “Opteon 1100 Liquid blowing Agent”, PU Magazine International 2019, 06, 376.

[16] Diendorf J.: 4th Generation Blowing Agents: Chances and Challenges with HFOs Rigid Technical Seminar Evonik, 2018.

[17] Mayer O.: "CFC Free. Low Density. Soft Flexible Slabstock Foams", Arco Chem. Europe Inc., Conference Proceedings, Polyurethanes 1992, 92, pp. 487-492.

[18] Treuling U., Horn P.: “CFC Replacement. Technical Applications for Microporous Materials", Conference Proceedings Polyurethanes 1995, 95, pp. 196-203.

[19] Obata H., Utsumi H., Ohkubo K. et al.: “New All Water Blown MDI Based Flexible Moulded Foam System", Conference Proceedings, Polyurethanes 1995, 95, pp. 406-412.

[20] Wada H., Fukuda H.: Journal of Cellular Plastics 2009, 45 (4), 293. https://doi.org/0.1177/0021955X09101206

[21] H2Foam Lite (LDC50)TM, The Evolution of Insulation, Icynene Europe 2018.

https://www.toftegaardgroup.dk/wp-content/uploads/2019/11/TDS-LDC50-EU-.pdf

[22] Jacobs L.J.M., Kemmere M.F., Keurenties J.T.F.: Green Chemistry 2008, 10 (7), 13. https://doi.org/10.1039/b801895b

[23] PLASTINUM Polyurethane Foaming with $\mathrm{CO}_{2}$-Linde Gaz.

https://www.linde-gaz.pl/en/products_and_supply/ plastic_rubber_solutions/plastinum_foam_p.html

[24] Supercritcal $\mathrm{CO}_{2}$ Technology for Polyurethane Spray Foam, UNDP Report 2013. 
http://multilateralfund.org/Our\%20Work/ DemonProject/Document\%20Library/7106a1\%20 super\%20C02\%20pu\%20foam.pdf

[25] US Pat. 44670899 (1984).

[26] US Pat. 5451612 (1995).

[27] US Pat. 5789 451A (1999).

[28] US Pat. 5874021 (1999).

[29] US Pat. 6316662 B (2001).

[30] US Pat. 6326412 B1 (2001).

[31] Da X., Liu C., Long Y. et al.: Applied Polymer Science 2019, 137, 48752.

https://doi.org/10.1002/app.48752
[32] Wianowski L., Białkowska A., Dobrowolski L. et al.: Polimery 2020, 65, 83. https://doi.org/10.14314/polimery.2020.2.1

[33] PL Pat. 230 383B1 (2017).

[34] Long Y., Zheng L., Gu Y. et al.: Polymer 2014, 55, 6494. https://doi.org/10.1016/j.polymer.2014.10.039

[35] Liu C., Long Y., Xie J., Xie X.: Polymer 2017, 116, 240. https://doi.org/10.1016/j.polymer.2017.03.079

[36] Long Y., An J., Xie X.: Arabian Journal of Chemistry 2020, 13, 3226.

https://doi.org/10.1016/j.arabjc.2018.10.007

Received 13 III 2020. 